\title{
Seasonality of Immunological and Health-State Parameters of Wild Broadnose Sevengill Shark, Notorynchus cepedianus ${ }^{\star}$
}

\author{
María Cruz Sueiro ${ }^{1, \dagger}$ \\ Cynthia A. Awruch ${ }^{1,2}$ \\ Alejo J. Irigoyen ${ }^{1}$ \\ Federico Argemi ${ }^{3}$ \\ María Gabriela Palacios ${ }^{1}$ \\ ${ }^{1}$ Centro para el Estudio de Sistemas Marinos, Centro \\ Nacional Patagónico-Consejo Nacional de Investigaciones \\ Científicas y Técnicas, Boulevard Brown 2915, Puerto \\ Madryn U9120ACD, Chubut, Argentina; ${ }^{2}$ School of Natural \\ Sciences, University of Tasmania, Sandy Bay Campus, \\ Private Bag 55, Tasmania 7001, Australia; ${ }^{3}$ Aquarium \\ Fundación Temaikèn, Ruta 25, kilómetro 1, Escobar 1625, \\ Buenos Aires, Argentina
}

Accepted 9/9/2018; Electronically Published 11/19/2018

\begin{abstract}
Seasonal fluctuation in environmental parameters can influence immune responses of vertebrates and consequently influence their health and disease resistance. Although seasonality of immune function is well documented in a broad range of vertebrate taxa, this information remains virtually unexplored in cartilaginous fish. Here we examine seasonal variation in immune and general-health parameters of freeliving adult broadnose sevengill sharks, Notorynchus cepedianus, along an annual cycle. We sampled sharks during autumn/winter (i.e., coolest temperatures and nonreproductive period) and spring/summer (i.e., warmest temperatures and active reproductive period) and assessed aspects of immunity, general condition, and reproductive hormone levels. A seasonal influence was observed in some, but not all, parameters evaluated. Lower lymphocyte counts and higher heterophil counts and granulocyte to lymphocyte $(\mathrm{G}: \mathrm{L})$ ratios were observed in sharks sampled during autumn/winter than in those sampled during spring/summer. On the other hand, total leukocyte counts, eosinophil counts, bacterial agglutination mediated by natural antibodies, and hematocrit did not vary seasonally. The observed seasonal patterns could be explained as (1) greater
\end{abstract}

\footnotetext{
${ }^{*}$ This paper was submitted in response to a call for papers for a Focused Issue on "Ecoimmunology."

†Corresponding author; email: cruz@cenpat-conicet.gob.ar, mariacruzsueiro@ gmail.com.
}

Physiological and Biochemical Zoology 92(1):24-36. 2018. (C) 2018 by The University of Chicago. All rights reserved. 1522-2152/2019/9201-8038 $\$ 15.00$. DOI: $10.1086 / 700573$ levels of stress based on the G:L ratio, (2) a sign of immunosuppression or depressed immune investment based on the low lymphocyte counts, and/or (3) a sign of ongoing infection based on the higher heterophil counts in the colder seasons with respect to the warmer ones. In addition, the pattern is in line with the notion that while acquired components are usually depressed by lower temperatures, some innate components might increase to offset that reduction. Immune and health-state parameters were mostly independent of reproductive hormone levels, providing little support for a trade-off with reproduction. Overall, the observed seasonal pattern in immunity of broadnose sevengill sharks could be related to changes in abiotic environmental condition, such as water temperature and photoperiod, although other factors such as availability of high-quality food may play a part.

Keywords: ecoimmunology, ecophysiology, elasmobranchs, steroid hormones, seasonal changes, Patagonia.

\section{Introduction}

Seasonal fluctuations in environmental parameters cause organisms to continuously adjust physiological and morphological characteristics to cope with different challenges during the annual cycle (Martin et al. 2008). These environmental influences are likely to be most prominent in species that live in highly seasonal locations, such as those common in temperate latitudes (Nelson et al. 2002). Seasonal changes in both abiotic (e.g., temperature, photoperiod, precipitation) and biotic (e.g., food availability, predation risk, parasite pressure) factors can result in seasonal patterns of energy and resource allocation, with changes in activity patterns, food intake, and body condition of individuals (Bowden et al. 2008; Martin et al. 2008). Given that immune defense is costly and generally dependent on body condition (Lochmiller and Deerenberg 2000; Lee 2006), seasonality can also modulate the immune responses of vertebrates and consequently modulate their health and disease resistance (Zapata et al. 1992; Nelson and Demas 1996; Bowden et al. 2007).

The vertebrate immune system is a network of many interacting cells, tissues, and soluble factors that collectively protect the body against disease. Broadly, the immune system comprises two main arms. The nonspecific innate arm constitutes the first line of defense and does not need prior exposure to antigens to respond. The more specific acquired arm is slower and requires prior exposure to mount a full response but provides immunological memory (Roitt et al. 1998). Both arms 
are composed of cellular and humoral components, some of which can be produced constitutively while others are produced or proliferate only in response to a challenge.

From an ecoimmunological point of view, variation in immune activity over the annual cycle is likely related to the relative costs and benefits of immune defense in different contexts and the consequent trade-offs animals may face between investing more in immune function versus other expensive processes such as growth or reproduction (Sheldon and Verhulst 1996; Lochmiller and Deerenberg 2000; Norris and Evans 2000). Reduced immune functions are commonly documented during reproductive events (Sheldon and Verhulst 1996; Lee 2006). This trade-off, proposed to result from resource reallocation from costly immune defenses to reproduction, might be mediated by reproductive hormones (Sheldon and Verhulst 1996; Martin et al. 2008). In the same way, depressed immune functions have been documented during other energetically demanding seasons. For instance, low ambient temperatures and decreased food availability during winter can induce immune depression relative to less demanding seasons (e.g., summer; Zapata et al. 1992; Bowden et al. 2008).

Seasonal changes in aspects of both innate and acquired immunity have been well documented in a broad range of vertebrate taxa: mammals (e.g., Lochmiller et al. 1994; Yellon et al. 1999), birds (e.g., Gonzalez et al. 1999; Owen-Ashley and Wingfield 2006), amphibians (e.g., Miodonski et al. 1996; Raffel et al. 2006; Madelaire et al. 2017), reptiles (e.g., El Ridi et al. 1981; Zimmermman et al. 2010), and teleost fish (e.g., Kumari et al. 2006; Bowden et al. 2007; Pascoli et al. 2011). General patterns across taxa are nevertheless elusive. Seasonal variation in immunity is complex and likely depends on the specific immune parameters measured and a combination of diverse factors such as latitude, life-history strategy, and disease threat, to name a few. Interestingly, although many aspects of the immune system of cartilaginous fish (Chondrichthyans: sharks, skates, rays, and chimaeras) have been thoroughly described (Luer et al. 2004; Arnold 2005; Lutton and Callard 2008; Crouch 2013), the question of whether and how immunity seasonally varies remains almost unexplored in this vertebrate group.

In this context, the goal of our study was to examine seasonal variation in immune and general-health parameters of free-living adult sharks and its possible relation to reproduction by looking into hormone levels. We studied the broadnose sevengill shark, Notorynchus cepedianus (Péron, 1807), family Hexanchidae, a species showing broad distribution worldwide that includes high-latitude locations. This viviparous shark reproduces during the warmer months and becomes reproductively inactive during the colder months. We sampled sharks during one annual cycle in a south temperate location showing pronounced seasonality. We assessed several immune and general-health parameters and measured reproductive hormone levels. As in most ecoimmunological studies of freeliving animals, the selection of immune and general-health parameters was a compromise between interpretability and feasibility of measurement in nonmodel organisms in their natural environment. Thus, we focused on measures that could be obtained with a single blood sample (i.e., did not require recapture) and that were not dependent on species-specific reagents.

The leukocyte profile provides insights regarding the major cellular effectors of the immune system (Beldoménico et al. 2008) and was assessed by estimation of the total leukocyte count (or total white blood cell count [WBC]) and of the different leukocyte types, including those involved in innate (e.g., neutrophils, monocytes, heterophils, eosinophils) and acquired (i.e., lymphocytes) immunity. Bacterial agglutination ability is mediated by plasma agglutinins such as natural antibodies and lectins. Natural antibodies can recognize a broad array of pathogens (e.g., bacteria, viruses) and are involved in early resistance against infection, constituting an important nexus between innate and acquired immune responses (reviewed by Ochsenbein and Zinkernagel 2000). Hematocrit constitutes a physiological index of condition and provides an estimate of aerobic capacity (Birchard 1997), whereas elevated granulocyte to lymphocyte (G:L) ratios are considered a reliable index of physiological stress in cartilaginous fish (Van Rijn and Reina 2010). Finally, we measured the circulating concentrations of plasma reproductive hormones, $17 \beta$-estradiol $\left(\mathrm{E}_{2}\right)$, progesterone $\left(\mathrm{P}_{4}\right)$, and testosterone $(\mathrm{T})$ in both male and female sharks (Awruch 2013).

\section{Methods}

This study was conducted in Punta Bajo $\left(42^{\circ} \mathrm{S}, 63^{\circ} \mathrm{W}\right)$ inside Caleta Valdés, a narrow and long bay where water temperature fluctuates seasonally between $10^{\circ} \mathrm{C}$ in August (Southern Hemisphere winter) and $19^{\circ} \mathrm{C}$ in January (Southern Hemisphere summer). Caleta Valdés is located in Península Valdés (Chubut, Patagonia, Argentina), a United Nations Educational, Scientific, and Cultural Organization Natural World Heritage Site categorized as a Managed Resource Protected Area according to the classification of conservation units by the International Union for Conservation of Nature (IUCN 2018).

Broadnose sevengill sharks were caught by longline and rod and reel during five daily sampling trips that were conducted between March 2016 and January 2017 (table 1). Longline soak times (i.e., the time period that the line is fishing) ranged from 30 to $120 \mathrm{~min}$ (average: $73 \mathrm{~min}$ ). Rod and reel fishing was conducted from shore, and fight time ranged from 1 to $12 \mathrm{~min}$. In all cases, sharks were gently placed on shore and rolled into the ventral position to allow for entering tonic immobility. During handling, seawater was pumped directly into the mouth cavity via a soft silicone bit piece supplied by a pump. Blood samples $(5 \mathrm{~mL})$ were drawn by venipuncture using heparinized, sterile plastic syringes fitted with 14-gauge needles within $10 \mathrm{~min}$ of capture. One drop of blood was immediately used to prepare a thin blood smear for leukocyte counts, and a microcapillary tube was filled for hematocrit measurement. The remaining blood was transferred to a sterile tube and kept on ice for $4-10 \mathrm{~h}$ until arrival at the laboratory, where plasma was separated by centrifugation $(1,000 \mathrm{~g})$ and stored at $-20^{\circ} \mathrm{C}$ until further analysis. 
Table 1: Date, corresponding season, mean water temperature, and sample size of adult broadnose sevengill sharks in each of the five sampling trips carried out during the study

\begin{tabular}{llccc}
\hline & & & \multicolumn{2}{c}{ No. sharks sampled } \\
\cline { 3 - 5 } Date of sampling & Season & $T\left({ }^{\circ} \mathrm{C}\right)$ & Females & Males \\
\hline March 12, 2016 & Summer & 16.5 & 7 & 1 \\
May 11, 2016 & Autumn & 12.5 & 4 & 7 \\
August 11, 2016 & Winter & 10 & 4 & 1 \\
November 5, 2016 & Spring & 15 & 13 & 8 \\
December 6, 2016 & Spring & 17 & 15 & 4 \\
January 31, 2017 & Summer & 19 & 6 & 0 \\
\hline
\end{tabular}

Total body length (TL, in $\mathrm{cm}$ ) and sex were recorded for each shark; the shark was then released back into the water. Only data for adult broadnose sevengill sharks $(n=70)$ were included in this study. Females with $>190 \mathrm{~cm}$ TL and males with $>175 \mathrm{~cm}$ TL were considered adults based on reproductive hormone data (Irigoyen et al. 2018). Juvenile individuals were few $(n=13)$ and were not considered further in this study; however, their immunological and health-related parameters and reproductive hormone levels are reported in appendix table A1 for future reference.

\section{Immunological Measurements}

Leukocyte Profile. Thin blood smears were air-dried, fixed with ethanol for $3 \mathrm{~min}$, and stained with Tinción 15 (Biopur). Smears were examined with a light microscope to estimate total WBC by counting all leukocytes in 10 consecutive $\times 400$ monolayer fields. Differential WBC (i.e., lymphocytes, eosinophils, heterophils, neutrophils, and monocytes) was assessed by classifying the first 200 leukocytes encountered under $\times 1,000$ magnification as described by Sueiro and Palacios (2016). Because there was no available description of the white blood cells for $\mathrm{No}$ torynchus cepedianus, we identified the different cell types on the basis of morphology following published leukocyte descriptions for other shark species (Arnold 2005; Campbell and Ellis 2007). Total counts for each type of leukocyte were calculated as the product of the respective proportion by the total WBC.

Bacterial Agglutination by Plasma. Bacterial agglutination was determined using a plate agglutination technique previously described for teleost fish species (Sahoo et al. 2008; Sueiro and Palacios 2016) that we adapted for use in N. cepedianus. Briefly, bacteria (Escherichia coli-ATCC 8739) were grown in sterile tryptic soy broth and then fixed in $1 \%$ formalin overnight at $4^{\circ} \mathrm{C}$. Fixed bacteria were washed three times with phosphatebuffered saline (PBS) and adjusted to a concentration of approximately $1 \times 10^{9}$ bacteria/mL. Plasma samples $(20 \mu \mathrm{L})$ were added to the first column of a 96-well plate and serially twofold diluted along the rows with PBS. A negative control (PBS instead of plasma) was included in each plate, and then $20 \mu \mathrm{L}$ of fixed bacteria were added to all wells. Plates were vortexed and incubated at ambient temperature overnight. Samples were run in duplicate, and agglutination titers were determined as $-\log _{2}$ of the highest dilution showing bacterial agglutination.

\section{Health-Related Parameters}

Hematocrit (i.e., the proportion of red blood cells in whole blood) was determined after centrifuging whole blood in heparinized glass capillary tubes for $5 \mathrm{~min}$. The proportions of granulocytes (neutrophils plus heterophils) and of lymphocytes obtained through the differential count were used to calculate the $G: L$ ratio for each individual. Eosinophils, the third type of granulocyte, are not included in the G: L ratio (Van Rijn and Reina 2010).

\section{Reproductive Hormone Measurements}

Plasma levels of $\mathrm{E}_{2}, \mathrm{P}_{4}$, and $\mathrm{T}$ were measured in both sexes by radioimmunoassay following Awruch et al. (2014). Briefly, testosterone antiserum was reconstituted by diluting $1: 10$ in PBS containing $0.1 \%$ gelatin and $0.01 \%$ thiomersal. Progesterone and $\mathrm{E}_{2}$ antisera were reconstituted by adding $5 \mathrm{~mL}$ of Tris buffer ( $\mathrm{pH} 8 ; 0.1 \mathrm{~m} \mathrm{HCl})$. Tritiated T, $\mathrm{E}_{2}$, and $\mathrm{P}_{4}(50 \mu \mathrm{L}$ each) were diluted in $5 \mathrm{~mL}$ of $100 \%$ ethanol and kept as separate stocks for the assay. Plasma samples $(200 \mu \mathrm{L})$ were extracted twice with ethyl acetate $(1 \mathrm{~mL})$. Samples were evaporated and then reconstituted in PBS. Each sample $(100 \mu \mathrm{L})$ was analyzed in duplicate and compared to the corresponding standard curve.

\section{Statistical Analyses}

Before analysis, data for both the winter and autumn samplings and the summer and spring samplings were pooled to increase sample sizes, given that these were rather low in the autumn and winter months. This pooling was based on data on reproductive cycle and relative water temperatures: autumn/winter (nonreproductive period and lower water temperature) and spring/summer (active reproductive period and higher water temperature; see table 1). Based on mating scars and previous information on the reproductive biology of the species (Ebert 1989, 1996; Lucifora et al. 2005; Awruch et al. 
2014), both sexes are considered reproductively active in warmer months, when mating takes place. In addition, we determined that despite the differences in capture time of sharks using the two different fishing gears (i.e., longline vs. rod and reel), physiological parameters were not affected by type of gear (Mann-Whitney tests, $U=1-141.5$; all $P>0.05$ ).

Immune and health-related parameters were examined using general linear models (GLMs) that included the fixed effect of season (spring/summer and autumn/winter), sex, their possible interaction, and TL as a covariable to control for individual size. On the other hand, reproductive hormone levels were examined separately for each sex using GLMs that included the fixed effect of season (spring/summer and autumn/winter) and TL as a covariable. Model residuals were examined for normality. Total WBC, total lymphocytes, bacterial agglutination titer, hematocrit, and the three reproductive hormones $\left(\mathrm{T}, \mathrm{E}_{2}\right.$, and $\left.\mathrm{P}_{4}\right)$ met the assumptions for parametric tests. Total heterophils, total eosinophils, and G:L ratio were arcsine-square root transformed before analysis. Monocytes and neutrophils were not included in the analyses given their high proportions of zeros.

To assess the potential associations of immune and generalhealth parameters with reproductive hormone levels at the individual level, we used correlations for females and males separately. Taking into account the GLM results, the following considerations were followed: immune and general-health parameters were analyzed separately by season in those cases where season was a significant effect; otherwise, data for both seasons were pooled and analyzed together. Likewise, in cases where total length was a significant covariate in the GLMs, partial correlations controlling for total length were used. Sample sizes differ among variables because not all measurements could be obtained for some individuals. The $P$ values below 0.05 were considered significant in all analyses. Statistical testing was performed using the software SPSS 15.0.

\section{Results}

Descriptive statistics for immunological and health-related parameters and reproductive hormone levels of adult broadnose sevengill sharks sampled during autumn/winter and spring/summer seasons are summarized in table 2 .

\section{Immunological Parameters}

Total WBC did not vary significantly between autumn/winter and spring/summer seasons but differed between sexes, with female sharks having higher counts than males. In addition, there was a significant negative effect of TL on total WBC (table 3; fig. 1A, 1B).

Lymphocytes were the most common white blood cells of broadnose sevengill sharks, followed by eosinophils and heterophils. Monocytes and neutrophils, although present, were in very low numbers (table 2). Basophils were not detected in any sample. Differential leukocyte counts showed seasonal variation for total lymphocyte and heterophil numbers but not for total eosinophil numbers. Lymphocyte counts were higher and heterophils lower during spring/summer than winter/autumn (table 3; fig. $1 C-1 E$ ). Besides, lymphocyte counts varied between sexes, being higher in females than in males, and were negatively affected by TL. Sex and TL did not explain significant variation in heterophil counts, and the same was observed for eosinophil counts except that these were positively affected by total body length, nor was there a significant interaction between sex and season in any of the leukocyte parameters. None of the factors/covariates of interest explained significant variation in bacterial agglutination titers (table 3; fig. $1 F$ ).

\section{Health-Related Parameters}

Hematocrit did not vary significantly with season, whereas the $G: L$ ratio was higher during autumn/winter than spring/ summer. Sex, the interaction between sex and season, and TL did not explain significant variation in either parameter (table 3; fig. $1 F, 1 G)$.

\section{Reproductive Hormones}

The analyses of reproductive hormones in males showed no changes in $\mathrm{P}_{4}$ levels with season, $\mathrm{E}_{2}$ levels were slightly higher in spring/summer than in autumn/winter, and T levels followed the same trend as $E_{2}$ but did not reach statistical significance. TL did not explain significant variation in male reproductive hormone levels (table 4; fig. 2). Female reproductive hormone levels did not vary significantly between seasons or with TL (table 4; fig. 2).

\section{Correlations between Immune and Health-Related Parameters and Reproductive Hormones}

Only three statistically significant correlations were found between immune and health-related parameters and reproductive hormone levels in sharks. For males, T levels correlated positively with total WBC when controlling for total length (partial correlation $r=0.558 ; P=0.032 ; n=15$ ), and $\mathrm{P}_{4}$ levels correlated positively with the $\mathrm{G}: \mathrm{L}$ ratio in the autumn/winter season (Pearson $r=0.898 ; P=0.006 ; n=7$ ). For females, only a negative correlation between $\mathrm{T}$ levels and lymphocyte counts was found during the spring/summer season after controlling for TL (partial correlation $r=-0.423$; $P=0.02 ; n=31$ ).

\section{Discussion}

The leukocyte profile and the G:L ratio (an index of stress derived from leukocyte counts) were dependent on seasonality in adult female and male broadnose sevengill sharks. Individuals sampled during the autumn/winter season (i.e., nonreproductive period and lower water temperatures) showed a lower number of lymphocytes and a higher number of heterophils compared to those sampled during the spring/summer season (i.e., active reproductive period and higher water 


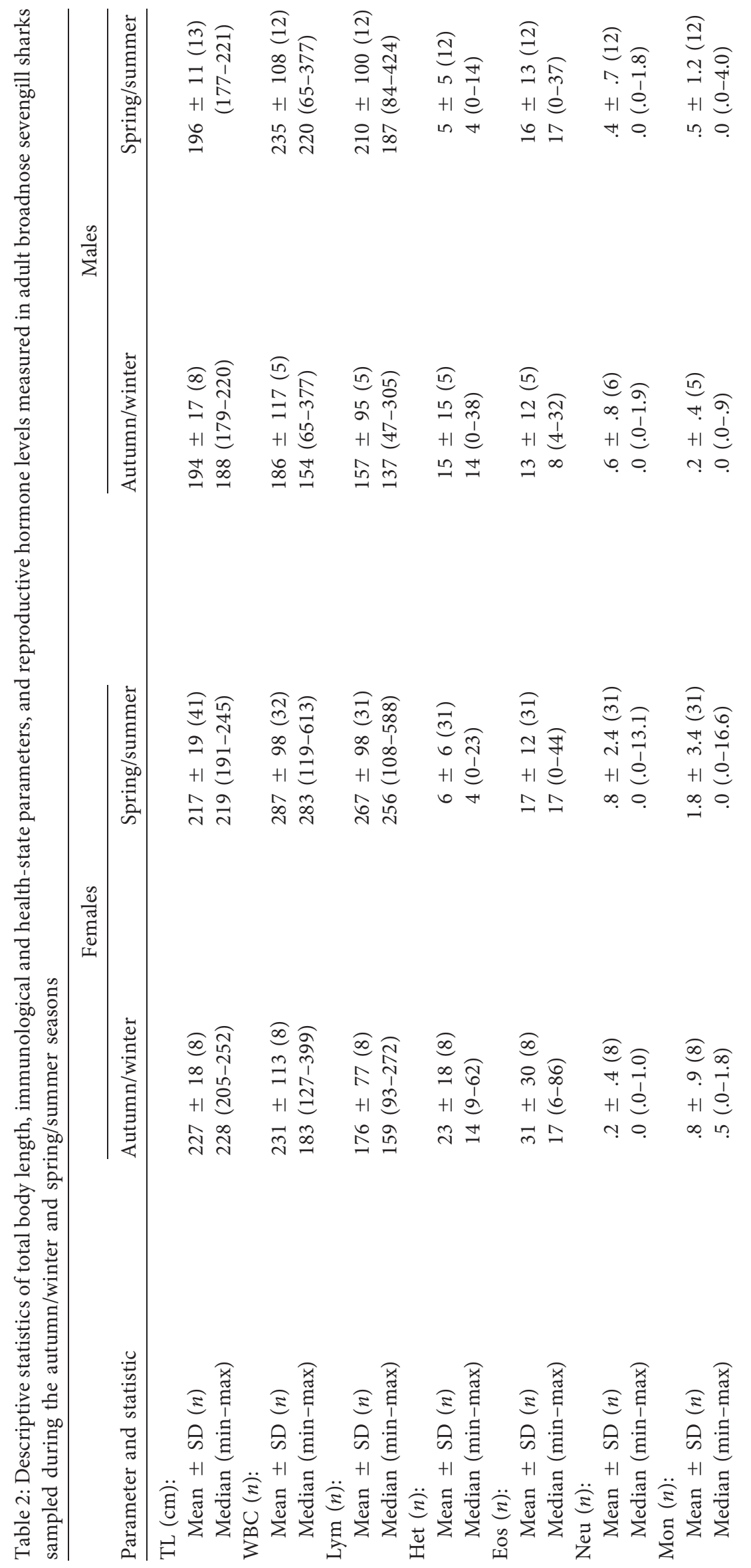




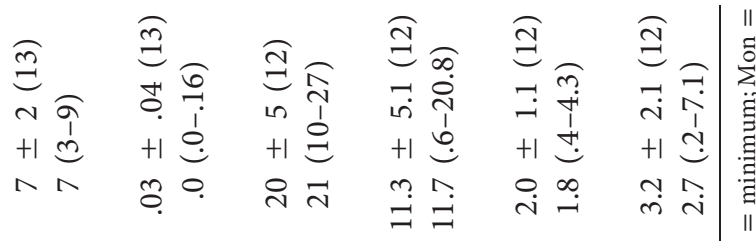

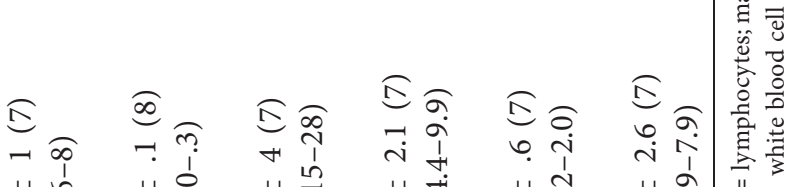

$$
\begin{aligned}
& +1 \text { end }+1 \text { d } \\
& \wedge \backsim \because \text { ก }
\end{aligned}
$$

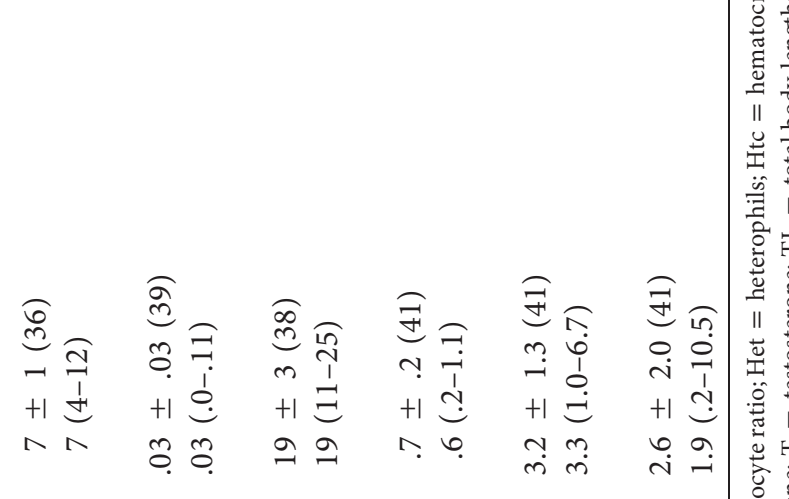

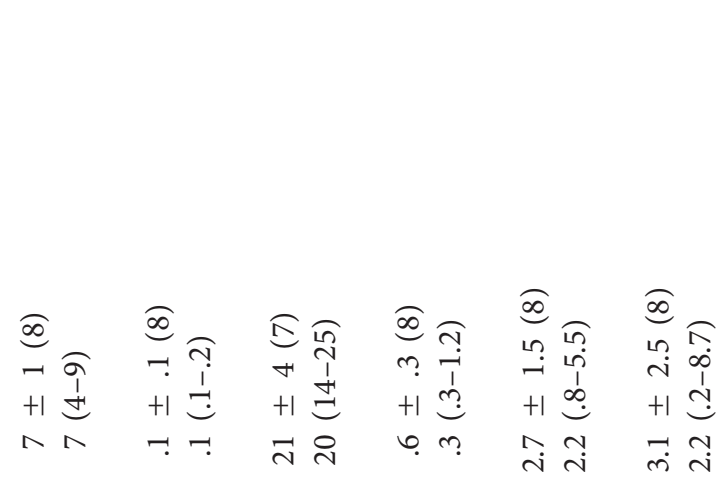

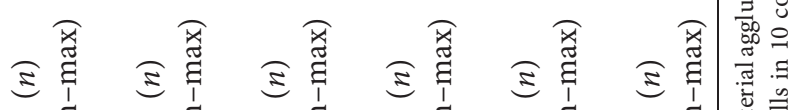

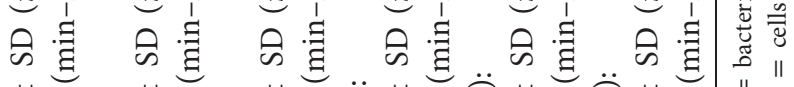

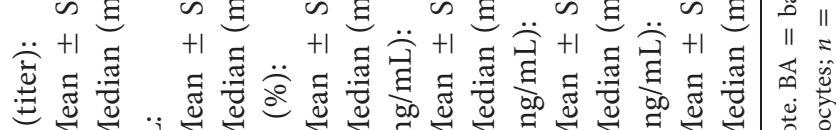

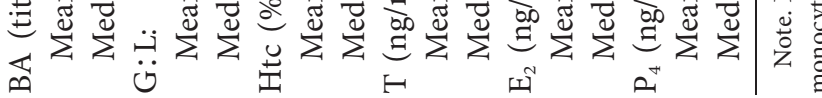


Table 3: General linear model for immunological and healthstate parameters of adult female and male broadnose sevengill sharks sampled during the autumn/winter and spring/ summer seasons

\begin{tabular}{|c|c|c|}
\hline Parameter and factor & Test & $P$ \\
\hline \multicolumn{3}{|l|}{ WBC: } \\
\hline Season & $F_{1,56}=1.66$ & .202 \\
\hline Sex & $F_{1,56}=14.42$ & $<.001$ \\
\hline Season $\times$ sex & $F_{1,56}=.05$ & .825 \\
\hline Covariate TL & $F_{1,56}=23.16$ & $<.001$ \\
\hline \multicolumn{3}{|l|}{ Lym: } \\
\hline Season & $F_{1,56}=4.41$ & .040 \\
\hline Sex & $F_{1,56}=12.87$ & .010 \\
\hline Season $\times$ sex & $F_{1,56}=.09$ & .764 \\
\hline Covariate TL & $F_{1,56}=24.94$ & $<.001$ \\
\hline \multicolumn{3}{|l|}{ Het: } \\
\hline Season & $F_{1,56}=17.72$ & $<.001$ \\
\hline Sex & $F_{1,56}=1.92$ & .171 \\
\hline Season $\times$ sex & $F_{1,56}=1.41$ & .240 \\
\hline Covariate TL & $F_{1,56}=.02$ & .891 \\
\hline \multicolumn{3}{|l|}{ Eos: } \\
\hline Season & $F_{1,56}=.20$ & .660 \\
\hline Sex & $F_{1,56}=3.636$ & .062 \\
\hline Season $\times$ sex & $F_{1,56}=.596$ & .444 \\
\hline Covariate TL & $F_{1,56}=5.613$ & .022 \\
\hline \multicolumn{3}{|l|}{ BA: } \\
\hline Season & $F_{1,59}=.04$ & .851 \\
\hline Sex & $F_{1,59}=.37$ & .544 \\
\hline Season $\times$ sex & $F_{1,59}=.40$ & .527 \\
\hline Covariate TL & $F_{1,59}=.59$ & .444 \\
\hline \multicolumn{3}{|l|}{ Htc: } \\
\hline Season & $F_{1,59}=2.92$ & .093 \\
\hline Sex & $F_{1,59}=.95$ & .335 \\
\hline Season $\times$ sex & $F_{1,59}=.01$ & .934 \\
\hline Covariate TL & $F_{1,59}=.04$ & .847 \\
\hline \multicolumn{3}{|l|}{ G:L: } \\
\hline Season & $F_{1,63}=33.99$ & $<.001$ \\
\hline Sex & $F_{1,63}=.00$ & .987 \\
\hline Season $\times$ sex & $F_{1,63}=.43$ & .514 \\
\hline Covariate TL & $F_{1,63}=.761$ & .386 \\
\hline
\end{tabular}

Note. Heterophils (Het), eosinophils (Eos), and granulocyte to lymphocyte ratio $(\mathrm{G}: \mathrm{L})$ were arcsine-square root transformed before analysis. $\mathrm{BA}=$ bacterial agglutination; Htc $=$ hematocrit; Lym = lymphocytes; $\mathrm{TL}=$ total body length; $\mathrm{WBC}=$ white blood cell count. Significant $P$ values are shown in boldface.

temperatures). These differences in leukocyte numbers were reflected in the higher $\mathrm{G}: \mathrm{L}$ ratio observed in sharks during the autumn/winter season. Low peripheral lymphocyte counts have been related to poor individual condition, immunosuppression, or poor immunological investment (Beldoménico et al. 2008), whereas high counts of heterophils have been related to ongoing infection, disease, and/or other stressful conditions (Beldoménico et al. 2008; Semeniuk et al. 2009). Thus, the observed seasonal pattern for sharks could be explained as (1) greater levels of stress based on the G:L ratio,
(2) a sign of immunosuppression or depressed immune investment based on the low lymphocyte counts, and/or (3) a sign of ongoing infection based on the high heterophil counts in the colder seasons with respect to the warmer ones. Since the total number of leukocytes (total WBC) did not differ significantly between seasons, changes in lymphocyte and heterophil numbers could be indicative of immuno-redistribution, an alteration in leukocyte "trafficking" between peripheral blood and other body compartments (Dhabhar et al. 1994, 1995). In addition, this result could be in line with the notion that while acquired components are usually depressed by lower temperatures, some innate components might increase to offset this reduction (Le Morvan 1998). Nevertheless, other measures of acquired immunity are needed to evaluate this hypothesis.

Our results in free-living sharks parallel studies in wild and farmed teleost fish that have demonstrated seasonal changes in circulating leukocyte counts in peripheral blood (Álvarez et al. 1998; Tort and Rovira 1998, 2011; Rohlenová et al. 2011). In particular, patterns of lower lymphocyte numbers during the winter have been documented for numerous species, including sea breams (Sparus aurata; Tort and Rovira 1998), common carps (Cyprinus carpio; Rohlenová et al. 2011), and several trout species (Álvarez et al. 1998; Papezíkova et al. 2016). Furthermore, studies in commercially important teleost fish (catfish: Ictalurus punctatus; sockeye salmon: Oncorhynchus nerka; common carp: C. carpio) have experimentally demonstrated the negative effect of cold water temperatures (within the natural ranges for each species) on lymphocyte numbers (Ainsworth et al. 1991; Le Morvan et al. 1998; Alcorn et al. 2002; Aman and Khan 2016) and function (reviewed by Bly and Clem 1992), which have been linked to disease outbreaks (Quiniou et al. 1998; Tort et al. 1998).

In addition to the leukocyte profile, we assessed an important humoral aspect of innate immunity of sharks using a bacterial agglutination assay. Our results showed no effect of season on bacterial agglutination titers, indicating that seasonality does not appear to have an impact on this measure, which reflects the constitutive function of natural antibodies and other agglutinins present in plasma. Among the few studies that have assessed the seasonality of bacterial agglutination in teleost fish, Swain et al. (2007) reported no differences in bacterial agglutination titers between the summer and winter seasons in Indian major carp Labeo rohita, although they did find significantly higher titers in the rainy season (reproductive period). Similarly, higher bacterial agglutination titers have been found in wild Patagonian rockfish (Sebastes oculatus) during the winter season (reproductive period) than in the summer season (nonreproductive period; Sueiro and Palacios 2016), suggesting a positive influence of reproductive status on this parameter and not supporting the idea of a reproductive trade-off. On the other hand, studies on teleost immunoglobulin $\mathrm{M}$ concentrations in serum (presumably representing natural antibodies) do not show consistent seasonal patterns across species, specific locations, and/ or sexes (e.g., Klesius 1990; Kortet et al. 2003; Vainikka et al. 2004; Rohlenová et al. 2011). 

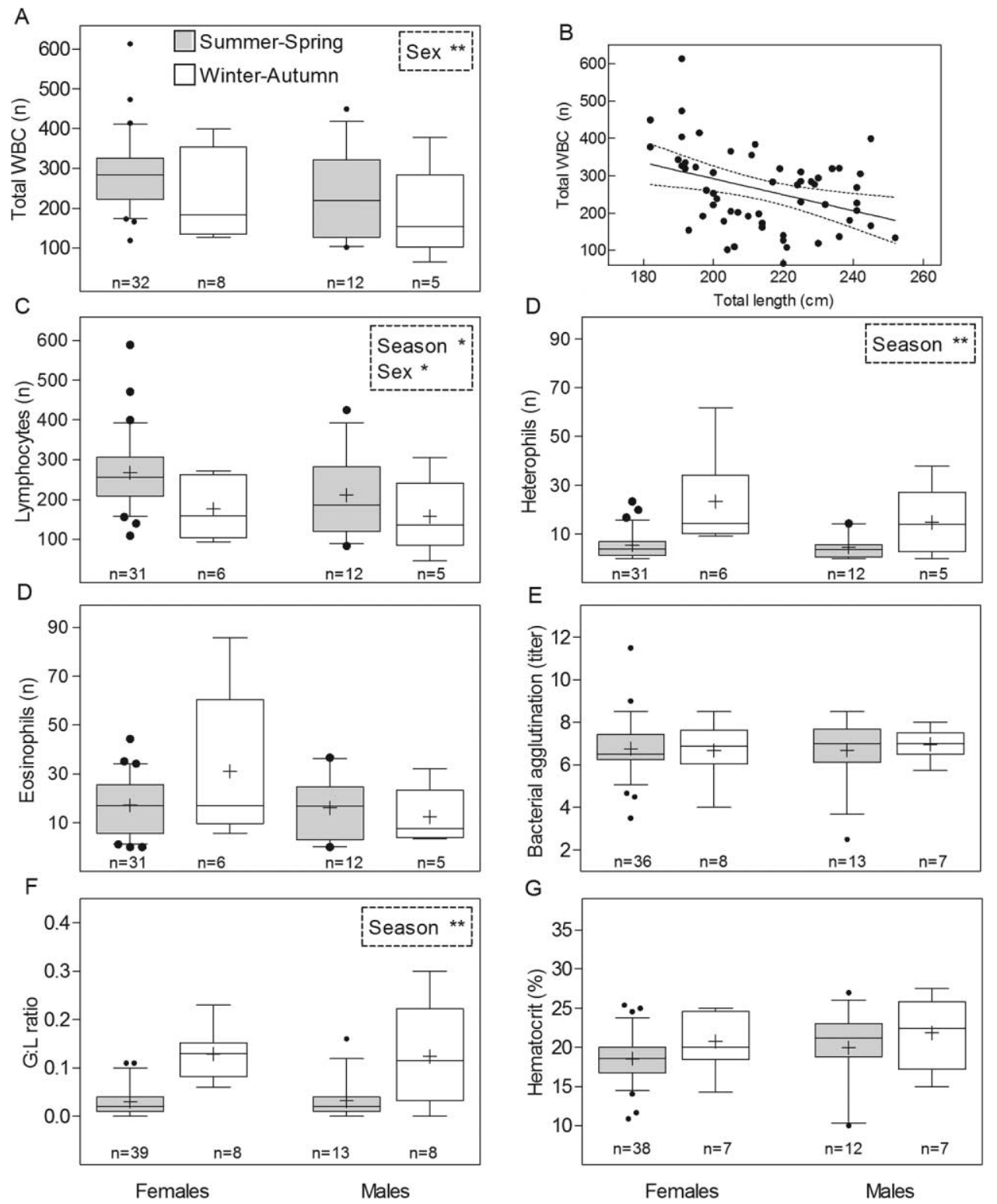

Figure 1. Boxplots of immune and general-health parameters of adult female and male broadnose sevengill sharks in the autumn/winter and spring/summer seasons. Significant effects, as evaluated by models in table 3, are shown with asterisks (one asterisk indicates that $P<0.05$; two asterisks indicates that $P<0.01$ ). Boxplots depict medians (horizontal lines inside boxes), means (plus signs), 25th and 75th percentiles (edges of boxes), 10th and 90th percentiles (whiskers), and outlying points included in the analyses (dots). $B$, Partial regression plot of significant correlation between total white blood cell counts (WBC) and total body length. $\mathrm{G}: \mathrm{L}=$ granulocyte to lymphocyte ratio; $n=$ number of cells in 10 consecutive $\times 400$ monolayer fields.

To our knowledge, only three previous studies in two different species have evaluated and reported a seasonal influence on aspects of immune function in cartilaginous fish. Atlantic sharpnose sharks (Rhizoporionodon terraenovae) sampled in summer and fall in Charleston, South Carolina, displayed higher levels of C-reactive protein, a biomarker of acute inflammation (Karsten and Rice 2004), and lower IgM concentrations (Karsten and Rice 2006) during summer (mating season and parturition) than fall (nonreproductive season), which the authors associated with a more energetically demanding and stressful summer season. On the other hand, female skates (Leucoraja erinacea) from Narragansett Bay, Rhode Island, showed an interaction between reproductive status and seasonality on in vitro proliferation of epigonal leukocytes (Lutton and Callard 2008). In this species, in which reproduction peaks in midsummer and midwinter, proliferation responses of reproductively active females were always higher than those of nonreproductive females and did not vary seasonally. In contrast, responses of non-reproductively active females were greater during winter (approaching the levels of reproductively 
Table 4: General linear model for reproductive hormone levels of adult female and male broadnose sevengill sharks sampled during the autumn/winter and spring/summer seasons

\begin{tabular}{|c|c|c|c|c|}
\hline \multirow[b]{2}{*}{ Parameter and factor } & \multicolumn{2}{|c|}{ Females } & \multicolumn{2}{|c|}{ Males } \\
\hline & Test & $P$ & Test & $P$ \\
\hline \multicolumn{5}{|l|}{$\mathrm{E}_{2}$ : } \\
\hline Season & $F_{1,48}=1.41$ & .241 & $F_{1,18}=4.69$ & .046 \\
\hline Covariate TL & $F_{1,48}=.56$ & .459 & $F_{1,18}=.15$ & .704 \\
\hline \multicolumn{5}{|l|}{$\mathrm{P}_{4}:$} \\
\hline Season & $F_{1,48}=.13$ & .721 & $F_{1,18}=.19$ & .672 \\
\hline Covariate TL & $F_{1,48}=.68$ & .413 & $F_{1,18}=.01$ & .927 \\
\hline \multicolumn{5}{|l|}{$\mathrm{T}:$} \\
\hline Season & $F_{1,48}=2.05$ & .159 & $F_{1,18}=3.72$ & .072 \\
\hline Covariate TL & $F_{1,48}=.98$ & .327 & $F_{1,18}=.01$ & .940 \\
\hline
\end{tabular}

Note. $\mathrm{E}_{2}=$ estradiol; $\mathrm{P}_{4}=$ progesterone; $\mathrm{T}=$ testosterone; $\mathrm{TL}=$ total body length. Significant $P$ values are shown in boldface.

active females) compared to spring, summer, and fall (Lutton and Callard 2008). These results, together with those from our study, indicate that some immune functions of cartilaginous fish can be influenced by seasonality, as it has been more extensively studied in the remaining vertebrate groups.

Reproductive hormone levels of male sharks showed some evidence of seasonal variation, with $\mathrm{E}_{2}$ and $\mathrm{T}$ levels tending to be higher during spring/summer, their active reproductive period, than autumn/winter. On the other hand, reproductive hormone levels of female sharks varied widely within spring/ summer and autumn/winter, resulting in no clear seasonal patterns. The latter could be related to the biennial reproductive cycle of females. During spring/summer, individual females can be either ready to ovulate, in final stages of gestation, or in postparturition, whereas during autumn/winter they can be in early stages of follicular development or gestating (Awruch et al. 2014). Immune and health-related parameters were mostly independent of reproductive hormone concentrations at the individual level, a result similar to that documented for a free-living teleost fish (Vainikka et al. 2004). Only three correlations between an immune parameter and a reproductive hormone were significant in broadnose sevengill sharks. Two positive associations were detected for male sharks, one between testosterone levels and total leukocyte counts and the other between progesterone levels and G:L ratios during autumn/ winter. On the other hand, only one negative association between testosterone levels and lymphocyte counts during spring/ summer was found for females. The latter could be seen as consistent with an immunosuppressive effect of testosterone on adaptive immunity of females during the reproductive period; however, this interpretation is unclear at present given the poorly understood role of female androgens in shark reproduction (Awruch et al. 2014). Overall, this study provides little support for a trade-off between immunity and reproduction in this system.

Several authors have reported seasonal aggregations of Notorynchus cepedianus in bay environments around the world in relation to feeding and mating activities (e.g., Ebert 1989; Lu-
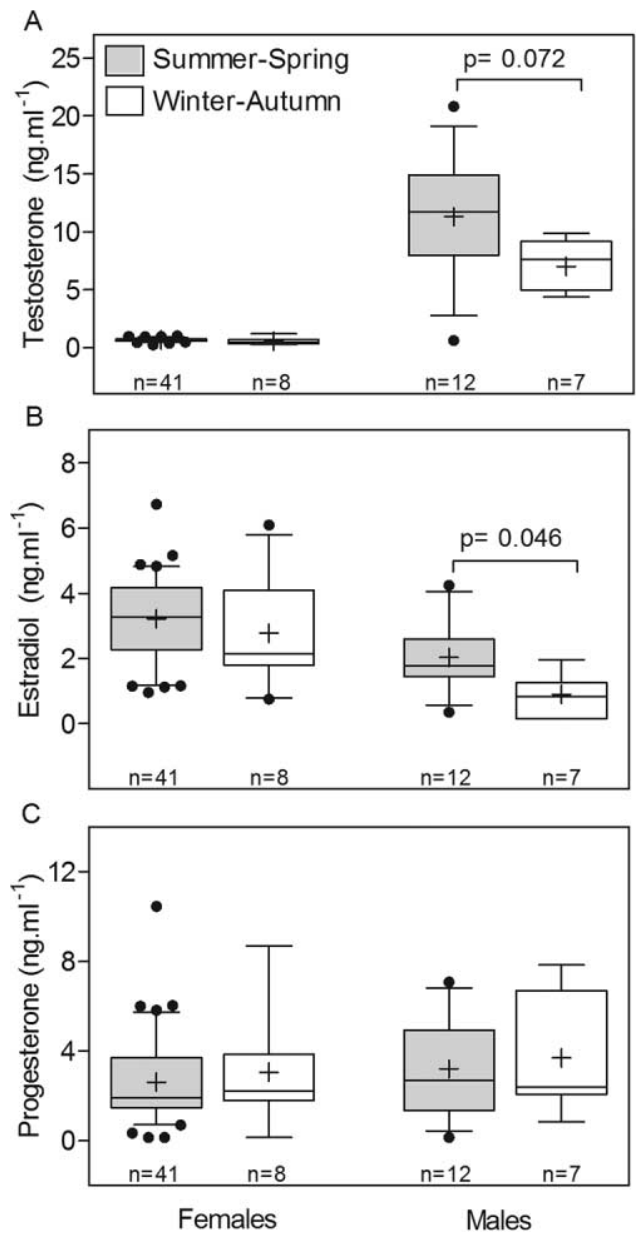

Figure 2. Boxplots of reproductive hormone levels of adult female and male broadnose sevengill sharks in the autumn/winter and spring/ summer seasons. The $P$ values of significant and marginal effects $(P$ values ranging from 0.05 to 0.1 ), as evaluated by models in table 4 , are shown in the panels. Boxplots depict medians (horizontal lines inside boxes), means (plus signs), 25th and 75th percentiles (edges of boxes), 10 th and 90th percentiles (whiskers), and outlying points included in the analyses (dots). 
cifora et al. 2005; Barnett et al. 2010; Williams et al. 2012; de Necker 2017). In this respect, it is remarkable that the reproductive season of the species in the study area is coupled with an intense foraging activity (Irigoyen et al. 2018). The availability of a high-quality nutrition source (elephant seal pups) during the active reproductive season could help explain the general absence of reproductive trade-offs with immune function observed in our study.

In summary, our study contributes to filling the present gap in information regarding seasonal variation in immunity in cartilaginous fish. Some, but not all, immune defense components measured were dependent on seasonal variability in broadnose sevengill sharks. This seasonal variation is potentially related to changes in abiotic environmental conditions such as water temperature and photoperiod, although other factors such as availability of high-quality food may play a part. Furthermore, male and female sharks did not differ in most of the parameters measured and showed similar seasonal patterns. Data on immunological and health-related parameters of the broadnose sevengill sharks collected in this study can be considered as reference values for the species. Future studies in this and other chondrichthyans, including diverse measures of immune function and parasite loads, are needed to better understand seasonal patterns and the underlying factors driving seasonal variation in immunity of this group.

\section{Acknowledgments}

We are grateful to N. Bovcon, M. Cuestas, M. Funes, M. Lupiano, M. Rossi, G. Trobbiani, G. Zamora, the Centro Nacional Patagónico, and the Temaiken crew for field support and handling of fish. We also thank the editor and anonymous reviewers for suggestions that helped improve our article. Funding was provided by the Agencia Nacional de Promoción Científica y Tecnológica (PICT 2013-3006 and 2013-1702) and the Save Our Seas Foundation (project 359/2016). Fieldwork included sampling within a World Natural Heritage Site and was authorized by the Secretaría de Turismo y Áreas Protegidas del Chubut (disposición 156-SsCyAP/17).

\section{APPENDIX}

Table A1: Descriptive statistics of total body length, immunological and health-state parameters, and reproductive hormone levels measured in immature broadnose sevengill sharks sampled during the autumn/winter and spring/summer seasons

\begin{tabular}{|c|c|c|}
\hline Parameter and statistic & Females $(n=10)$ & Males $(n=3)$ \\
\hline \multicolumn{3}{|l|}{$\mathrm{TL}(\mathrm{cm}):$} \\
\hline Mean $\pm \mathrm{SD}$ & $172 \pm 10$ & $171 \pm 3$ \\
\hline Median (min-max) & $176(156-182)$ & $172(168-174)$ \\
\hline \multicolumn{3}{|l|}{ Lym (\%): } \\
\hline Mean $\pm S D$ & $85 \pm 8$ & $89 \pm 4$ \\
\hline Median (min-max) & $86(71-94)$ & $89(84-93)$ \\
\hline \multicolumn{3}{|l|}{ Het $(\%)$ : } \\
\hline Mean $\pm S D$ & $3 \pm 2$ & $6 \pm 5$ \\
\hline Median (min-max) & $3(1-6)$ & $3(3-12)$ \\
\hline \multicolumn{3}{|l|}{ Eos $(\%):$} \\
\hline Mean $\pm S D$ & $12 \pm 7$ & $5 \pm 2$ \\
\hline Median (min-max) & $12(3-24)$ & $5(4-8)$ \\
\hline \multicolumn{3}{|l|}{ Neu (\%): } \\
\hline Mean $\pm \mathrm{SD}$ & $1 \pm 1$ & 0 \\
\hline Median (min-max) & $1(0-3)$ & \\
\hline \multicolumn{3}{|l|}{ Mon (\%): } \\
\hline Mean $\pm S D$ & $1 \pm 1$ & $.2 \pm .3$ \\
\hline Median (min-max) & $1(0-3)$ & $.0(.0-.5)$ \\
\hline \multicolumn{3}{|l|}{ BA (titer): } \\
\hline Mean $\pm S D$ & $6 \pm 2$ & $5 \pm 2$ \\
\hline Median (min-max) & $7(3-9)$ & $6(4-7)$ \\
\hline \multicolumn{3}{|l|}{ G:L: } \\
\hline Mean $\pm \mathrm{SD}$ & $.04 \pm .03$ & $.07 \pm .06$ \\
\hline Median $(\min -\max )$ & $.04(.00-.08)$ & $.03(.03-.14)$ \\
\hline
\end{tabular}


Table A1 (Continued)

\begin{tabular}{lcc}
\hline Parameter and statistic & Females $(n=10)$ & Males $(n=3)$ \\
\hline Htc $(\%):$ & $19 \pm 2$ & $17 \pm 1$ \\
$\quad$ Mean \pm SD & $19(16-22)$ & $17(17-18)$ \\
Median $($ min-max $)$ & $.5 \pm .1$ & $8.9 \pm 4.5$ \\
$\mathrm{~T}(\mathrm{ng} / \mathrm{mL}):$ & $.5(.3-.7)$ & $6.9(5.7-14.2)$ \\
$\quad$ Mean \pm SD & $2.4 \pm .8$ & \\
$\quad$ Median $(\min -\max )$ & $2.4(1.2-4.0)$ & $2.3 \pm .6$ \\
$\mathrm{E}_{2}(\mathrm{ng} / \mathrm{mL}):$ & & $2.6(1.6-2.7)$ \\
$\quad$ Mean $\pm \mathrm{SD}$ & $1.9 \pm 1.2$ & $2.1 \pm .1$ \\
$\quad$ Median $(\min -\max )$ & $1.7(.2-3.9)$ & $2.1(1.9-2.2)$ \\
$\mathrm{P}_{4}(\mathrm{ng} / \mathrm{mL}):$ &
\end{tabular}

Note. $\mathrm{BA}=$ bacterial agglutination; $\mathrm{E}_{2}=$ estradiol; Eos = eosinophils; $\mathrm{G}: \mathrm{L}=$ granulocyte to lymphocyte ratio; Het $=$ heterophils; Htc $=$ hematocrit; Lym = lymphocytes; $\max =$ maximum; $\min =$ minimum; Mon $=$ monocytes $; \mathrm{Neu}=$ neutrophils; $\mathrm{P}_{4}=$ progesterone; $\mathrm{T}=$ testosterone; $\mathrm{TL}=$ total body length.

\section{Literature Cited}

Ainsworth A.J., C. Dexiang, P.R. Waterstrat, and T. Greenway. 1991. Effect of temperature on the immune system of channel catfish (Ictalurus punctatus). I. Leukocyte distribution and phagocyte function in the anterior kidney at $10^{\circ} \mathrm{C}$. Comp Biochem Physiol 100:907-912.

Alcorn S.W., A.L. Murray, and R.J. Pascho. 2002. Effects of rearing temperature on immune functions in sockeye salmon (Oncorynchus nerka). Fish Shellfish Immunol 12:303-334.

Álvarez F., B.E. Razquin, A.J. Villena, and A.G. Zapata. 1998. Seasonal changes in the lymphoid organs of wild brown trout, Salmo trutta L: a morphometrical study. Vet Immunol Immunopathol 64:267-278.

Aman S.A.H. and K.M.H. Khan. 2016. Effect of different levels of water temperature on blood parameters of common carp (Cyprinus carpio). Res Opin Anim Vet Sci 6:178180 .

Arnold J.E. 2005. Hematology of the sandbar shark, Carcharhinus plumbeus: standardization of complete blood count techniques for elasmobranchs. Vet Clin Pathol 34:115-123.

Awruch C.A. 2013. Reproductive endocrinology in chondrichthyans: the present and the future. Gen Comp Endocrinol 192: 60-70.

Awruch C.A., S.M. Jones, M. García Asorey, and A. Barnett. 2014. A non-lethal assessment of the reproductive status of broadnose sevengill sharks (Notorynchus cepedianus) to determine the significance of habitat use in coastal areas. Conserv Physiol 2:cou013.

Barnett A., D. Stevens, S.D. Frusher, and J.N. Semmens. 2010. Seasonal occurrence and population structure of the broadnose sevengill shark Notorynchus cepedianus in coastal habitats of south-east Tasmania. J Fish Biol 77:1688-1701.

Beldomenico P.M., S. Telfer, S. Gebert, L. Lukomski, M. Bennett, and M. Begon. 2008. The dynamics of health in wild field vole populations: a haematological perspective. J Anim Ecol 77:984997.

Birchard G.F. 1997. Optimal hematocrit: theory, regulation and implications. Am Zool 37:65-72.

Bly J.E. and W. Clem. 1992. Temperature and teleost immune function. Fish Shellfish Immunol 2:159-171.

Bowden T.J. 2008. Modulation of the immune system of fish by their environment. Fish Shellfish Immunol 25:373-383.

Bowden T.J., K.D. Thompson, A.L. Morgan, R.M.L. Gratacap, and S. Nikoskelainen. 2007. Seasonal variation and the immune response: a fish perspective. Fish Shellfish Immunol 22:695-706.

Campbell T. and C. Ellis. 2007. Avian and exotic animal hematology and cytology. 3rd ed. Blackwell, Ames, IA.

Crouch K., L.E. Smith, R. Williams, W. Cao, M. Lee, A. Jensen, and H. Dooley. 2013. Humoral immune response of the small-spotted catshark, Scyliorhinus canicula. Fish Shellfish Immunol 34:1158-1169.

De Necker L. 2017. The trophic dynamics of the broadnose sevengill shark (Notorynchus cepedianus) in False Bay, South Africa, using multiple tissue stable isotope analysis. MSc diss. University of Cape Town.

Dhabhar F.S., A.H. Miller, B.S. McEwen, and R.L. Spencer. 1995. Effects of stress on immune cell distribution: dynamics and hormonal mechanisms. J Immunol 154:1638-1644.

Dhabhar F.S., A.H. Miller, M. Stein, B.S. McEwen, and R.L. Spencer. 1994. Diurnal and acute stress-induced changes distribution in peripheral blood leukocyte subpopulation. Brain Behav Immun 8:66-79.

Ebert D.A. 1989. Life history of the sevengill shark, Notorynchus cepedianus Peron, in two northern California bays. Calif Fish Game 75:102-112.

- 1996. Biology of the sevengill shark Notorynchus cepedianus (Peron, 1807) in the temperate coastal waters of southern Africa. S Afr J Mar Sci 17:93-103. 
El Ridi R., N. Badir, and S. El Rouby. 1981. Effect of seasonal variations on the immune system of the snake, Psammophis schokari. J Exp Zool 216:357-365.

Gonzalez G., G. Sorci, and F. de Lope. 1999. Seasonal variation in the relationship between cellular immune response and badge size in male house sparrows (Passer domesticus). Behav Ecol Sociobiol 46:117-122.

Irigoyen A.J., A.M. De Wysiecki, G. Trobbiani, N. Bovcon, C.A. Awruch, F. Argemi, and A.J. Jaureguizar. 2018. Habitat use, seasonality and demography of an apex predator in a marine temperate environment: the case of the sevengill shark Notorynchus cepedianus in northern Patagonia. Mar Ecol Prog Ser 603:147-160.

IUCN (International Union for Conservation of Nature). 2018. The IUCN Red List of Threatened Species. https:// www.iucnredlist.org/species/39324/10200310. Accessed November 10, 2018. doi:10.2305/IUCN.UK.2005.RLTS.T39324A 10200310.en.

Karsten A.H. and C.D. Rice. 2004. c-reactive protein levels as a biomarker of inflammation and stress in the Atlantic sharpnose shark (Rhizoprionodon terraenovae) from three southeastern USA estuaries. Mar Environ Res 58:747-751.

_. 2006. Serum IgM levels against select marine bacteria in the Atlantic sharpnose shark (Rhizoprionodon terraenovae) from three estuaries. Comp Biochem Physiol C 143: 355-361.

Klesius P.H. 1990. Effect of size and temperature on the quantity of immunoglobulin in channel catfish, Ictalurus punctatus. Vet Immunol Immunopathol 24:187-195.

Kortet R., J. Taskinen, T. Sinisalo, and I. Jokinen. 2003. Breeding-related seasonal changes in immunocompetence, health state and condition of the cyprinid fish, Rutilus rutilus, L. Biol J Linn Soc 78:117-127.

Kumari J., P.K. Sahoo, T. Swain, S.K. Sahoo, A.K. Sahu, and B.R. Mohanty. 2006. Seasonal variation in the innate immune parameters of the Asian catfish Clarias batrachus. Aquaculture 252:121-127.

Lee K.A. 2006. Linking immune defenses and life history at the levels of the individual and the species. Int Comp Biol 46: 1000-1015.

Le Morvan C., D. Troutaud, and P. Deschaux. 1998. Differential effects of temperature on specific and nonspecific immune defenses in fish. J Exp Biol 201:165-168.

Lochmiller R.L. and C. Deerenberg. 2000. Trade-off in evolutionary immunology: just what is the cost of immunity? Oikos 88:87-89.

Lochmiller R.L., M.R. Vestey, and S.T. McMurry. 1994. Temporal variation in humoral and cell-mediated immuneresponse in a Sigmodon hispidus population. Ecology 75: 236-245.

Lucifora L.O., R.C. Menni, and A.H. Escalante. 2005. Reproduction, abundance and feeding habits of the broadnose sevengill shark Notorynchus cepedianus in north Patagonia, Argentina. Mar Ecol Prog Ser 289:237-244.

Luer C.A., C.J. Walsh, and A.B. Bodine. 2004. The immune system of sharks, skates and rays. Pp. 369-395 in J.C.
Carrier, J.A. Muisck, and M.R. Heithaus, eds. Biology of sharks and their relatives. CRC, Boca Raton, FL.

Lutton B.V. and I.P. Callard. 2008. Influence of reproductive activity, sex steroids, and seasonality on epigonal organ cellular proliferation in the skate (Leucoraja erinacea). Gen Comp Endocrinol 155:116-125.

Madelaire C.B., I. Sokolova, and F.R. Gomes. 2017. Seasonal patterns of variation in steroid plasma levels and immune parameters in anurans from Brazilian semiarid area. Physiol Biochem Zool 4:415-433.

Martin L.B., Z.M. Weil, and R.J Nelson. 2008. Seasonal changes in vertebrate immune activity: mediation by physiological trade-offs. Philos Trans R Soc B 363:321-339.

Miodonski A.J., J. Bigaj, J. Mika, and B. Plytycz. 1996. Seasonspecific thymic architecture in the frog, Rana temporaria: SEM studies. Dev Comp Immunol 20:129-137.

Nelson R.J. and G.E. Demas. 1996. Seasonal changes in immune function. Q Rev Biol 71:511-548.

Nelson R.J., G.E. Demas, S.L. Klein, and L.J. Kriegsfeld. 2002. Seasonal patterns of stress, immune function, and disease. Cambridge University Press, New York.

Norris K. and M.R. Evans. 2000. Ecological immunology: life history trade-offs and immune defense in birds. Behav Ecol 11:1-19.

Ochsenbein A.F. and R.M. Zinkernagel. 2000. Natural antibodies and complement link innate and acquired immunity. Immunol Today 21:624-630.

Owen-Ashley N.T. and J.C. Wingfield. 2006. Seasonal modulation of sickness behavior in free-living northwestern song sparrows (Melospiza melodia morphna). J Exp Biol 209:3062-3070.

Papežíková I., J. Mareš, L. Votjek, P. Hyršl, Z. Marková, A. Šimková, J. Bartoňková, S. Narátil, and M. Palíková. 2016. Seasonal changes in immune parameters of rainbow trout (Oncorhynchus mykiss), brook trout (Salvelinus fontinalis) and brook trout $\times$ Artic charr hybrids (Salvelinus fontinalis $\times$ Salvelinus alpinus). Fish Shellfish Immunol 57:400-405.

Pascoli F., G.S. Lanzano, E. Negrato, C. Poltronieri, A. Trocino, G. Radaelli, and D. Bertotto. 2011. Seasonal effects on hematological and innate immune parameters in sea bass Dicentrarchus labrax. Fish Shellfish Immunol 31:1081-1087. Quiniou S.M.A., S. Bigler, L.W. Clem, and J.E. Bly. 1998. Effects of water temperature on mucous cell distribution in channel catfish epidermis: a factor in winter saprolegniasis. Fish Shellfish Immunol 8:1-11.

Raffel T.R., J.R. Rohr, J.M. Kieseckers, and P.J. Hudson. 2006. Negative effects of changing temperature on amphibian immunity under field conditions. Funct Ecol 20:819-828.

Rohlenová K., S. Morand, P. Hyršl, S. Tolarová, M. Flajšhans, and A. Šimková. 2011. Are fish immune systems really affected by parasites? an immunoecological study of common carp (Cyprinus carpio). Parasites Vectors 4:1-18.

Roitt I.M., J. Brostoff, and D.K. Male. 1998. Immunology. Mosby, London.

Sahoo P.K., K. Das Mahapatra, J.N. Saha, A. Barat, M. Sahoo, B.R. Mohanty, B. Gjerde, J. Ødegard, M. Rye, and R. Salte. 
2008. Family association between immune parameters and resistance to Aeromonas hydrophila infection in the Indian major carp, Labeo rohita. Fish Shellfish Immunol 25:163169.

Semeniuk C.A.D., S. Bouregon, S.L. Smith, and K.D. Rothley. 2009. Hematological differences between stingrays at tourist and non-visited sites suggest physiological costs of wildlife tourism. Biol Conserv 142:1818-1829.

Sheldon B.C. and S. Verhulst. 1996. Ecological immunology: costly parasite defence and trade-offs in evolutionary ecology. Trends Ecol Evol 11:317-321.

Sueiro M.C. and M.G. Palacios. 2016. Immunological and health-state parameters in the Patagonian rockfish Sebastes oculatus: their relation to chemical stressors and seasonal changes. Fish Shellfish Immunol 48:71-78.

Swain P., S. Dash, P.K. Sahoo, P. Routray, S.K. Sahoo, S.D. Gupta, P.K. Meher, and N. Sarangi. 2007. Non-specific immune parameters of brood Indian major carp Labeo rohita and their seasonal variation. Fish Shellfish Immunol 22:38-43.

Tort L., F. Prados, J. Rotllant, and S. Crespo. 1998. Winter syndrome in the gilthead sea bream Sparus aurata: immunological and histopathological features. Fish Shellfish Immunol 8:37-47.
Vainikka A., E.I. Jokinen, R. Kortet, and J. Taskinen. 2004. Gender- and season-dependent relationship between testosterone, oestradiol and immune function in wild roach. J Fish Biol 64:227-240.

Van Rijn J.A. and R.D. Reina. 2010. Distribution of leukocytes as indicators of stress in the Australian swellshark, Cephaloscyllium laticeps. Fish Shellfish Immunol 29:534-538.

Williams G.D., K.S. Andrews, S.L. Katz, M.L. Moser, N. Tolimieri, D.A. Farrer, and P.S. Levin. 2012. Scale and pattern of broadnose sevengill shark Notorynchus cepedianus movement in estuarine embayments. J Fish Biol 80:1380-1400.

Yellon S.M., L.A. Teasley, O.R. Fagoaga, H.C. Nguyen, H.N. Truong, and L. Nehlsen-Cannarella. 1999. Role of photoperiod and the pineal gland in $\mathrm{T}$ cell-dependent humoral immune reactivity in the Siberian hamster. J Pineal Res 27: 243-248.

Zapata A.G., A. Varas, and M. Torroba. 1992. Seasonal variations in the immune system of lower vertebrates. Immunol Today 13:142-147.

Zimmerman L.M., R.T. Paitz, L.A. Vogel, and R.M. Bowden. 2010. Variation in the seasonal patterns of innate and adaptive immunity in the red-eared slider (Trachemys scripta). J Exp Biol 213:1477-1483. 